\title{
Hydrobiologia
}

September 2014, Volume 736, Issue 1, pp 139-154

http://dx.doi.org/10.1007/s10750-014-1900-y

\section{Depth-dependent gene flow in Gulf of Mexico cold seep Lamellibrachia tubeworms (Annelida, Siboglinidae)}

\author{
Dominique A. Cowart ${ }^{1,2,}$, Kenneth M. Halanych ${ }^{3}$, Stephen W. Schaeffer ${ }^{1}$, Charles R. Fisher ${ }^{1}$
}

\begin{abstract}
${ }^{1}$ Department of Biology, The Pennsylvania State University, 208 Erwin W. Mueller Laboratory, University Park, PA, 16801, USA

${ }^{2}$ Unité Environnement Profond - DEEP du, Département des Ressources physiques et Ecosystèmes de Fond de mer (REM), IFREMER - Institut Français de Recherche pour l'Exploitation de la MER, B.P. 70, 29280, Plouzané, France

${ }^{3}$ Department of Biological Sciences, Auburn University, 101 Rouse Life Sciences Building, Auburn, AL, 36849, USA
\end{abstract}

*: Corresponding author : Dominique A. Cowart, email address : dominique.cowart@gmail.com

\begin{abstract}
:
Lamellibrachia vestimentiferan tubeworms form aggregations at hydrocarbon cold seeps in the deep Gulf of Mexico (GoM), creating structures that provide living space for other fauna. In the GoM, three Lamellibrachia taxa vary in morphology and depth ranges: Lamellibrachia luymesi (300-950 m), Lamellibrachia sp. 1 (950-2,604 m), and Lamellibrachia sp. 2 (1,175-3,304 m). While Lamellibrachia sp. 2 is consistently identified as a separate species, L. luymesi and sp. 1 cannot be discriminated using barcoding markers cytochrome oxidase subunit 1 (COI) and large ribosomal subunit rDNA (16S). To determine if limited gene flow was a factor in the formation of these taxa, we employed more quickly evolving markers, including mitochondrial cytochrome $B$ (CYTB), hemoglobin subunit B2 intron (HbB2i), and six polymorphic microsatellites; microsatellites were amplified across $45 \mathrm{~L}$. luymesi and sp. 1 individuals. Additionally, we used microsatellites to ask whether populations of Lamellibrachia sp. 1 and sp. 2 show evidence of significant structure. Despite a lack of resolution seen with CYTB and $\mathrm{HbB2i}$, L. luymesi and sp. 1 form genetically differentiated clusters at the cross-amplified microsatellites. Furthermore, we find no evidence for population structure for either Lamellibrachia sp. 1 or sp. 2 across the GoM.
\end{abstract}

Keywords: Deep sea ; Hydrocarbon seep; Microsatellite; Population structure; Siboglinid; Vestimentiferan tubeworm 


\section{Introduction}

Clarifying mechanisms that drive speciation in marine environments can be challenging, as few absolute barriers to gene flow exist in the ocean; regions separated by hundreds of kilometers can be connected genetically, while populations in close proximity can be genetically distinct (Palumbi, 1994). Abiotic factors such as temperature, hydrostatic pressure, salinity, nutrient input, sediment type and ocean currents therefore play a significant role in the formation of species in the sea, as variations in these conditions can drive ecological differentiation (Gage \& Tyler, 1992; Schluter \& Nagel, 1995).

For a species to colonize deep-sea habitats, appropriate life stages must have the physiological tolerance to cope with low temperatures, low food density, and high pressures (Carney, 2005; Aquino-Souza et al., 2008), as well as be able to find and settle upon appropriate substrates. Below $500 \mathrm{~m}$, ambient light is absent and salinity is fairly constant (Bruun, 1957; Somero, 1992a; Lalli \& Parsons, 1993). However, temperature can vary from about $2^{\circ} \mathrm{C}$ below $2000 \mathrm{~m}$ to 8 to $10^{\circ} \mathrm{C}$ at $500 \mathrm{~m}$, and hydrostatic pressure increases continuously with depth (Bruun, 1957; Saunders \& Fofonoff, 1976; Carney, 2005). Shifts in temperature and pressure linked to increasing depth can influence many physiological and biochemical processes in animals, for example, the disruption of protein structures is one of many physiological effects associated with abrupt changes in pressure (Somero, 1992b; Oliphant et al., 2011).

Due to the limits of accessibility and thus sampling, factors influencing speciation in deepsea benthic animals are relatively poorly known, however, there are some studies that explore this topic. Etter \& Rex (1990) illustrated that regardless of developmental mode, deep dwelling snail species in the western North Atlantic occupy broader depth ranges when compared to shallow species, suggesting that biotic and physical constraints lessen with increasing depth. Howell et al. (2004) found that three reproductively isolated morphotypes of the Atlantic seastar Zoroaster fulgens live in a depth range $>3,000 \mathrm{~m}$ and are stratified with respect to depth. Furthermore, Rex \& Etter (2010) suggest that many marine species defined by morphological criteria are thought to have broad bathymetric ranges, when they may actually be composed of sibling species separated by depth. More recently, Jennings et al. (2013) identified low levels of gene flow between shallow and deep populations of the protobranch bivalve, Nucula atacellana, suggesting that environmental factors associated with depth are responsible for the discontinuity across bathymetric ranges.

The vestimentiferan genus Lamellibrachia contains at least six described species that are distributed along the western Pacific (L. satsuma, L. juni, L. columna), eastern Pacific ( $L$. barhami), the Mediterranean Sea (L. anaximandri) and the Gulf of Mexico (L. Iuymesi) (Webb, 1969; Southward, 1991; Miura et al., 1997; McMullin et al., 2003; Miura and Kojima, 2006; Southward et al., 2011). Lamellibrachia from the Gulf of Mexico are some of the most extensively studied seep tubeworms, as these seep communities were among the first to be discovered in the 1980s (Brooks et al., 1987; Kennicutt et al., 1988). Lamellibrachia in the Gulf of Mexico are distributed across the Louisiana Slope, which ranges from about 300 $\mathrm{m}$ depth at the continental shelf edge to about 3,300 $\mathrm{m}$ at the salt deformation edge of the Sigsbee Escarpment (Cordes et al., 2009). The most commonly recognized seep tubeworm, Lamellibrachia luymesi (van der Land \& NØrrevang, 1975), is found on the upper Louisiana Slope from about 300 to $950 \mathrm{~m}$. Two morphologically distinct and undescribed taxa, Lamellibrachia sp. 1 and sp. 2, are distributed across the lower Louisiana 
slope (> $1000 \mathrm{~m}$ ), as well as at the base of the Florida Escarpment. Lamellibrachia sp. 1 ranges from $950-2604 \mathrm{~m}$, while Lamellibrachia sp. 2, which is the most rarely observed of the three Gulf of Mexico Lamellibrachia, ranges from 1175 - 3304 m (Miglietta et al., 2010).

The three Gulf of Mexico Lamellibrachia taxa differ morphologically; members of each group have gill lamellae, which are used for gas exchange and are a major feature that distinguishes Lamellibrachia from Escarpia tubeworms (Jones, 1985). However, each Lamellibrachia taxon differs in the numbers of gill lamellae as well as in the size and length of the vestimentum (Miglietta et al., 2010).

Initial investigations employing two mitochondrial genes, Cytochrome Oxidase subunit 1 (COI) and large ribosomal subunit gene (16S rDNA), clearly distinguished L. sp. 2 from the other Gulf of Mexico Lamellibrachia, but did not distinguish Lamellibrachia luymesi and sp. 1 (Miglietta et al., 2010). Both COI (used for barcoding" (Hebert et al., 2003)) and 16S genes have slow rates of change in seep vestimentiferans, and do not differentiate some other vestimentiferan taxa that are distinct species (McMullin et al., 2003; Cowart et al., 2013). Therefore, the lack of differentiation in these genes may mislead researchers to identify Lamellibrachia luymesi and sp. 1 as the same species.

Species replacement" with depth has been documented at various marine ecosystems and is often a result of differences in abiotic factors such as temperature and pressure (MacArthur, 1972; Brown, 1984). The same families of organisms are present at cold seep habitats worldwide and include the siboglinid polychaetes, bathymodioline mussels and vesicomyid bivalves (Carney, 1994; Sibuet and Olu, 1998). However at Gulf of Mexico seeps, there is significant species replacement at depths between $800-1000 \mathrm{~m}$, so although the seep taxa are related across depths at the family level, most species present below about $1000 \mathrm{~m}$ differ from those above $1000 \mathrm{~m}$ (Carney, 2005; Cordes et al., 2010). A notable exception is the seep mussel Bathymodiolus childressi, which has a depth range of at least $1600 \mathrm{~m}$ in the Gulf of Mexico (Cordes et al., 2007).

To determine if limited gene flow played a role in the formation of Lamellibrachia luymesi and sp. 1 tubeworms in the Gulf of Mexico, we asked whether these two -morphospecies" form one genetically undifferentiated population, or two genetically distinct populations, as suggested by their morphology and known depth distributions. To address this question, we employed different types of genetic markers: the mitochondrial marker Cytochrome B (CYTB) which has been found to be phylogenetically informative in other animal groups (Johns and Avise, 1998), the Exon Priming Intron Crossing (EPIC) nuclear marker Hemoglobin subunit B2 intron $(\mathrm{HbB} 2 \mathrm{i})$, as nuclear introns tend to be more variable than conserved exon regions and are used for finer level phylogenetic differentiation (Sang, 2002), and finally, six polymorphic microsatellite loci. We suggest that Lamellibrachia luymesi and sp. 1 will form genetically distinct clusters (-genotypic clusters", Mallet, 1995) following the pattern of species replacement seen in other Gulf of Mexico seep taxa. Alternatively, if the Lamellibrachia are genetically undifferentiated, this suggests that Lamellibrachia luymesi and sp.1 are a single polymorphic taxon inhabiting a depth range of $>2304 \mathrm{~m}$ in the Gulf of Mexico.

We also provide initial data on population structure of Lamellibrachia sp. 1 and $\mathrm{sp}$. 2 to identify geographic scales of effective larval dispersal in each group. Although previous studies have employed microsatellite markers to determine if genetic structure exists within other vestimentiferans living at cold seeps (McMullin et al., 2010, Cowart et al., 2013), 
presence of genetic structure in Lamellibrachia populations living at seeps below $1000 \mathrm{~m}$ remains unknown.

\section{Methods}

\subsection{Sample Collection and Preparation}

Tubeworms were collected using two manned submersibles and one remotely operated vehicle from 13 hydrocarbon seep sites during research cruises that occurred between 1995 and 2010 (Figure 1, Table 1). Lamellibrachia luymesi individuals were sampled from four locations across the upper Louisiana Slope using the deep submergence vehicle Johnson Sea Link II on the research vessel Seward Johnson, operated by Harbor Branch Oceanographic Institution. Lamellibrachia sp. 1 and sp. 2 individuals were collected from eight and six locations, respectively, across the lower Louisiana Slope using remotely operated vehicle Jason I/ on the National Oceanic and Atmospheric Administration (NOAA) vessel Ronald Brown and the deep submergence vehicle Alvin on the research vessel Atlantis (Table 1). Sample preparation and DNA extraction protocols were performed as described in Cowart et al. (2012).

\subsection{Marker development and sequencing analyses}

Lamellibrachia specific Cytochrome B (CYTB) and Hemoglobin subunit B2 intron (HbB2i) primers were developed by using Escarpia CYTB and HbB2i primers to amplify partial fragments in Lamellibrachia (see Cowart et al., 2013 for Escarpia primers), which were aligned to design Lamellibrachia specific primers. For the HbB2i fragment, primers were designed within the exons to flank the first intron in Lamellibrachia. All PCR reactions and gel electrophoresis were performed as described in Miglietta et al. (2010), with annealing occurring for $1.5 \mathrm{~min}$ at $51^{\circ} \mathrm{C}$ for $\mathrm{CYTB}$ and $54^{\circ} \mathrm{C} \mathrm{HbB2i}$. PCR products were purified using the ExoSAP-IT® protocol (USB, Affymetrix); purified PCR products were then submitted to the Penn State Genomics Core Facility (University Park, PA) and run on 3730XL DNA sequencer. Sequences were assembled and conflicts in the reads from the two strands were edited using DNASTAR package 8.1 (Lasergene, Madison, WI, USA) and Geneious Pro v5.5.5 (Biomatters Ltd.). For the $\mathrm{HbB2} \mathrm{i}$ fragment, two sites had simultaneous amplification of two different nucleotides (heterozygous sites). Three individuals exhibited the ambiguity at one site, and one individual exhibited ambiguity at the other site. As none of the sequences were heterozygous at both sites, two different haplotypes, $a$ " and $b$ " for the heterozygous individuals were generated, where $a$ " has one nucleotide and " $b$ " has the second nucleotide. These original and additional haplotypes were denoted as A" and B" for each of the heterozygous individuals and included in all analyses. Alignments were done using ClustalW (Thompson et al., 1994) and MUSCLE (Edgar, 2004) implemented through MEGA 5.05 (www.megasoftware.net, Tamura et al. 2011). Phylogenetic analyses were estimated with MEGA using the Maximum Likelihood (ML) method with 1000 bootstrap replicates and between species pairwise distances were calculated using the pdistance model with 1000 bootstrap replicates (Tamura \& Nei, 1993; Tamura et al., 2004). Previously published sequences for Escarpia laminata (CYTB accessions KF201512 KF201542; HbB2i accessions KF201543 - KF201572) served as the outgroup taxon for the phylogenetic analyses. To test for departures from selective neutrality of the genes, Tajima's D (1989) statistic was estimated using Arlequin v3.5 (Schneider \& Lischer, 2009). 
Median-joining haplotype networks were created using the program Network v4.611 (Bandelt et al., 1999, available at www.fluxus-engineering.com).

\subsection{Microsatellite development and analyses}

Microsatellite loci used in this study were developed previously by McMullin and co-workers (2004) or with the aid of an Illumina transcriptome library produced from one adult $L$. luymesi. For the Illumina run, RNA extraction was done using the RNeasy kit (Qiagen) with on-column DNase digestion, following the manufacturer's protocol. RNA was quantified with a Qubit fluorometer (Invitrogen) and evaluated on a 1\% SB agarose gel. One $\mu \mathrm{g}$ of total RNA was used to synthesize first-strand cDNA using the SMART cDNA library construction kit (Clonetech) following the manufacturer's instructions except that the kit's 3 ' oligo was replaced with Cap-Trsa-CV oligonucleotide (5'AAGCAGTGGTATCAACGCAGAGTCGCAGTCGGTACTTTTTTCTTTTTTV-3') as per Kocot et al. (2011). The Advantage 2 PCR system (Clonetech) was used to amplify fulllength cDNA. As few PCR cycles (usually 17-19 rounds) as possible were used during amplification. Samples were sent to Hudson Alpha Institute for Biotechnology (Huntsville, $A L)$ for sequencing. Sequencing used the Illumina TrueSeq paired-end (PE) library preparation protocol (following manufacturer's protocol). Samples were run as 1/6 of a lane (i.e. - 6 samples per lane) on an Illumina Hi-Seq 2500 using 2x100bp PE chemistry. Truseq was used for insert sizes, which were a few to several hundred base pairs in length.

To identify short tandem repeats, Lamellibrachia luymesi sequence reads were uploaded and searched using the Tandem Database v2.30 program (Gelfand et al., 2006) and potential primer pairs for the repeats were identified using Primer 3 v.0.4.0 (Rozen \& Skaletsky, 1999). Primers with lengths between $18-27 \mathrm{bp}, \mathrm{GC}$ content $\geq 50 \%$, and melting temperature $\geq 50^{\circ} \mathrm{C}$ were chosen because they had a high likelihood of amplifying the fragment. Each marker was tested for variability using the M13-tagging approach with DNA from several individuals (Schuelke, 2000; see Cowart et al., 2012 for details on primer screening and fragment analyses). From the M13 screening phase, eighteen potential primer sets were identified, and ten of these sets amplified across to Lamellibrachia sp. 1, while five amplified across to Lamellibrachia sp. 2. Additional screening of chromatograms by eye and testing for genotyping errors (described below) found five primers sets for Lamellibrachia luymesilsp. 1 and four primer sets for Lamellibrachia sp. 2 to be polymorphic and without obvious genotyping errors; these primer sets in addition to one microsatellite marker from McMullin and others (2004) were used in downstream analyses (Table 2).

The automated calls of microsatellite allele lengths can sometimes differ by less than the size of the repeat unit. To correct for genotyping errors and allele calls that were offset by lengths less than the repeat unit, we used a binning process in which allele counts were assigned to the nearest repeat unit, as described in detail in Cowart et al. (2013). To investigate the quality of the loci, GENEPOP v4.1 (Raymond \& Rousset, 1995), MicroChecker v2.2.3 (van Oosterhout et al., 2004) and INEst v.1.0 (Chybicki \& Burczyk, 2009, Individual Inbreeding Model) were used to test for presence of linkage disequilibrium and null alleles. Estimates of observed and expected heterozygosity, as well as exact tests for departures from Hardy-Weinberg Equilibrium (HWE) were computed with the aid of Arlequin v3.5. The False Discovery Rate approach (FDR) was used to adjust the probability cutoff for tests of significant linkage disequilibrium and departures from HWE (Benjamini \& Yekutieli, 2001). FDR was computed with the Q-value (Storey \& Tibshirani, 2003), which 
was implemented in the statistical software $R$ version 2.10.1 ( $R$ Development Core Team 2009). Wright's F-statistics were estimated using FSTAT v.2.9.3.2 (Wright, 1951; Goudet, $1995)$ to estimate genetic differentiation among populations and levels of inbreeding ( $F_{S T}$ and $F_{I S}$ ). The program HP-RARE (Kalinowski, 2005) was used for the computation of allelic richness at each sampling location, controlled for sample size.

To determine if there was genetic structure among Lamellibrachia taxa, population assignment tests were executed in STRUCTURE v2.3.x (Pritchard et al., 2000) and EDENetworks v.2.16 (Kivelä et al., in prep). For STRUCTURE, independent allele frequencies and admixed populations were assumed, and three replicate simulations were run using various values for $K$ (number of populations) with 100,000 Markov Chain Monte Carlo repetitions for each cluster and a burn-in of 10,000 cycles. EDENetworks assigns individuals to population clusters while screening for the presence of hybrids based the Rozenfeld Distance (ancestral polymorphism) (Rozenfeld et al., 2007; Rozenfeld et al., 2008, Moalic et al., 2011). Resulting networks define genetic distances (links) to assign individuals (nodes) to their -species" of origin without an a priori hypothesis. The percolation threshold, an inner property of EDENetworks, is the level by which a fully connected network is split into discrete clusters (Stauffer and Aharony, 1994; Watts, 2004). To identify presence of genetic structuring at the individual, subpopulation and total population scales, we calculated Analysis of Molecular Variance (AMOVA) statistics (Excoffier et al., 1992) with the aid of GenoDive v.2.0b22 (Meirmans \& Hedrick, 2011).

\section{Results}

\subsection{Mitochondrial gene and nuclear intron sequences}

The complete CYTB dataset consisted of a 380bp fragment amplified in 16 Lamellibrachia luymesi, 15 Lamellibrachia sp. 1 (Accessions KF201512- KF201542) and six Escarpia individuals. We did not amplify all 45 Lamellibrachia luymesi and sp. 1 individuals because, similar to previous mitochondrial data from CO1 and 16S, CYTB does not resolve Lamellibrachia luymesi and sp. 1 (Figure A.1; see supporting information for all distances estimates). A haplotype network of CYTB (Figure 2) identifies the two most common haplotypes shared between both Lamellibrachia luymesi and sp. 1; these haplotypes differ by only two mutational changes. Additionally, the network shows three haplotypes unshared between the two Lamellibrachia; one Lamellibrachia luymesi haplotype and two Lamellibrachia sp. 1 haplotypes, each contain more than one individual, providing evidence for differentiation of the two groups.

The complete HbB2i dataset consisted of a 668bp fragment amplified in 15 Lamellibrachia luymesi, 15 Lamellibrachia sp. 1 (Accessions KF201543 - KF201572) and six Escarpia individuals. The HbB2i topography also did not differentiate Lamellibrachia luymesi and sp. 1 (Figure A.2). Within the entire HbB2i fragment, two sites were identified as heterozygous. Three individuals exhibited heterozygosity at aligned nucleotide 552 ( $G$ or $T$ ), while one individual was heterozygous at aligned nucleotide 594 (A or T). Two haplotypes for each heterozygous individual were generated to identify each nucleotide as a distinct sequence, and these additional haplotypes were included in network and phylogenetic analyses. The $\mathrm{HbB} 2 \mathrm{i}$ haplotype analysis identifies the most common haplotype as shared between Lamellibrachia luymesi and sp. 1 (Figure 2). Two haplotypes unique to Lamellibrachia sp. 1 
containing two or more individuals were connected to the major haplotype by only one mutation change, whereas one haplotype unique to L. luymesi contained two individuals was present.

Demographic history of Lamellibrachia was assessed by examining Tajima's $D$ in both Lamellibrachia luymesi and sp. 1 at CYTB and $\mathrm{HbB} 2 \mathrm{i}$. None of the $D$ values were significantly different from zero (Table A.3), suggesting that these genes do not show evidence for recent bottleneck or expansion events.

\subsection{Microsatellite loci}

Summary statistics for the six-microsatellite loci amplified across Lamellibrachia luymesi and sp. 1 are shown in Table 3. All tests for linkage disequilibrium failed to reject random association of alleles at different loci $(p>0.05)$. Mean null allele frequencies were below 0.18 for all loci in all populations but one (Table A.4), and there was no evidence of stuttering or large allele dropout seen in any of the loci tested in this study. A total of 82 alleles were observed across all six loci and 45 Lamellibrachia luymesi and $\mathrm{sp} .1$ individuals tested. The average number of alleles across loci was 7.3 for Lamellibrachia luymesi and 8.3 for Lamellibrachia sp. 1. The largest number of alleles was found at the locus L454_11 for both Lamellibrachia luymesi (13) and sp. 1 (19). For Lamellibrachia luymesi and sp. 1, the mean observed heterozygosity was 0.59 and 0.61 , respectively, and two of the 12 population and locus combinations departed from HWE at a probability cutoff of 0.01 and an FDR of 0.01 .

STRUCTURE and network analyses both support the occurrence of two genetically distinct groups of Lamellibrachia, differentiated by depth (Figure 3). Network analyses show congruent results of two well-defined clusters with one hybrid link at percolation thresholds higher than 50. The link was present between an Lamellibrachia luymesi individual from site GC234 and an Lamellibrachia sp. 1 individual from site GC600, two sites in relatively close geographic proximity and separated by about $640 \mathrm{~m}$ in depth (Figures 1 and 3 ). Despite this connection between the two localities, clustering identifies strong genetic structuring by depth, which is also supported by AMOVA analyses $(p=0.001$, Table 4$)$.

\subsection{Population genetics of deep Lamellibrachia}

To test for the presence of genetic differentiation across the Mississippi Canyon (Sammarco et al., 2012), we pooled samples based on the location of sites to the west or east of the canyon (see Cairns et al., 1993 and McMullin et al. 2010 for descriptions of deep GoM faunal regions associated with the Mississippi Canyon).

Summary statistics for microsatellites amplified in west and east groups of Lamellibrachia sp. 1 and sp. 2 are detailed in Tables 3 and 5. Examination of twenty-four individuals for Lamellibrachia sp. 1 uncovered 52 alleles across all loci. The average number of alleles across all loci was eight for the west and 4.8 for the east Gulf of Mexico. The largest number of alleles was found at locus L454_11 for both the west (18) and the east (8). The mean observed heterozygosity was $0.5 \overline{9}$ and 0.79 for the west and east groups, respectively. Two departures from HWE were observed at locus L454_13 at a probability cutoff of 0.01 and an FDR of 0.01 , while the $F_{S T}$ value for west versus east was below 0.001 (all $F_{S T}$ values in Table A.5). 
The Lamellibrachia sp. 2 dataset was divided into west, east and far-east groups as per previously described faunal regions (Cairns et al., 1993, McMullin et al. 2010). Thirty-one individuals were examined with 20 alleles observed across all loci. The average number of alleles across all loci was 2.7 for west, 4.7 for east and 2.5 for far-east (Table 6). The largest number of alleles was detected at the locus L454_19 for west (4), east (5) and fareast (3) locations. For the west group, mean observed heterozygosity was 0.56 , while for the east and far-east groups, the mean observed heterozygosity was 0.61 and 0.81 . No departures from HWE were observed. $\mathrm{F}_{\mathrm{ST}}$ values indicate higher dissimilarity between west and far-east groups $\left(F_{S T}=0.071\right)$, with west and east groups being most similar (Table A.5).

Despite differences in sample sizes between locations, there was no detectable difference in the average allelic or private allelic richness among groups in either Lamellibrachia sp. 1 or sp.2 $(p>0.05)$. Furthermore, STRUCTURE analyses did not detect the presence of genetic structuring among the western or eastern groups in either Lamellibrachia sp. 1 or sp. 2. In addition to low $F_{S T}$ values, AMOVA testing did not identify significant population differentiation in either Lamellibrachia sp. 1 or $\mathrm{sp} .2$ ( $p>0.05)$, supporting a single genetically indistinguishable population within Lamellibrachia sp.1 and within sp. 2 across the region.

\section{Discussion}

\subsection{Utility of mitochondrial genes versus microsatellite markers for identifying seep vestimentiferans}

DNA barcoding" refers to the use of a specific region in the genome for rapid and accurate identification of species (Valentini et al., 2008). In most animals, the proposed region of choice is the COI molecule, for which universal primers have been developed. Despite its successful implementation for discriminating among species in other taxa, COI fails to differentiate between morphologically distinct, depth-separated and/or geographically separate species of Lamellibrachia and Escarpia cold seep vestimentiferan tubeworms (Black et al., 1997; Andersen et al., 2004; Miglietta et al., 2010; Cowart et al., 2013).

In this study, we find that CYTB also does not separate Lamellibrachia lumyesi and sp. 1 as determined from morphology and collection depths. These findings are not surprising, given that CYTB is a mitochondrial gene that exhibits similar evolutionary patterns as $\mathrm{COI}$ and 16S, despite its variability in other animal groups (Johns and Avise, 1998). Several factors have been suggested for the low rate of mutation seen in vestimentiferan mitochondrial genes, including the possibility of young lineages where the time since divergence is small (incomplete lineage sorting, Maddison and Knowles, 2006), long generation times in seep tubeworms, differences between male and female effective population sizes, as well as selective sweeps which may reduce variation at this locus (McMullin et al., 2003; Bazin et al., 2006; Galtier et al., 2009).

The intron regions of nuclear genes tend to be more variable then mitochondrial genes and nuclear exons, and can therefore be useful for detecting fine scale phylogenetic 
relationships (Sang, 2002). Cowart et al. (2013) employed the Hemoglobin subunit B2 intron and uncovered three distinct species of Escarpia, a finding that is congruent with morphological and geographic descriptions. However, the HbB2i locus did not differentiate Lamellibrachia luymesi and sp. 1 from the Gulf of Mexico. Although nuclear genomic characteristics differ from that of the mitochondria in terms of the presence of introns, evolutionary rate, mode of inheritance, and recombination, both DNA types can be subject to similar evolutionary processes, including selective sweeps and incomplete lineage sorting (Broughton and Harrison, 2003), factors which may also explain the low variation seen at the Lamellibrachia nuclear intron locus tested in this study. Haplotype networks for both CYTB and HbB2i indicated that the most common haplotypes were shared between the two groups, but also identified haplotypes unique to each group. Unique haplotypes composed of more than one individual provide evidence for possible divergence among the Lamellibrachia luymesi and sp. 1, although incomplete lineage sorting at both loci cannot be ruled out.

Analyses of the six cross-amplified microsatellite loci clearly separate Lamellibrachia luymesi and sp. 1 into distinct non-admixed genotypic clusters, a definition of -species" described by Mallet (1995). Use of microsatellites to discriminate tubeworm species was also previously employed within the genus Escarpia; nine microsatellites cross amplified in three taxa allowed for the identification of three distinct groups (Cowart et al., 2013). In addition to providing more evidence for the existence of two separate species, results here continue to support that mitochondrial genes are not variable enough to uncover finer scale vestimentiferan relationships and that more variable markers, such as microsatellites, can allow identification of closely related species that have disparate habitat ranges and dissimilar morphology.

\subsection{Separate versus overlapping environmental ranges}

The most likely factors to be responsible for genetic divergence and reproductive isolation observed between Lamellibrachia luymesi and sp. 1 are those associated with physiological adaptations to different depths (temperature and pressure) rather than classical niche differentiation which likely isolates the co-occurring deep living taxa Lamellibrachia sp. 1, sp. 2 and $E$ laminata. Population divergence often occurs along environmental gradients (Jennings et al. 2013). In the deep sea, vertical species ranges are heavily influenced by factors such as larval tolerance to temperature and pressure, orientation in the water column and swimming behavior (Somero, 1992a; Tyler \& Young, 1998; Cordes et al., 2007). Lamellibrachia adults produce lecithotrophic larvae, which can persist in the water column for about three weeks and have an estimated dispersal distance of about 100km from their natal sites (Young et al., 1996; Tyler \& Young, 1999; Pradillon and Gaill, 2007; Young et al., 2012).

During their time in the water column, Lamellibrachia larvae may experience limits to their temperature tolerance. Young et al. (2012) observed that Lamellibrachia luymesi larvae cannot tolerate temperatures found above the thermocline, however it is currently unknown if Lamellibrachia luymesi larvae are also unable to tolerate temperatures as low as $4^{\circ} \mathrm{C}$ along the Lower Louisiana Slope, which may restrict their lower depth boundaries as well. Additionally, Young and Tyler (1993) demonstrated that low pressures affect larval development mechanisms and can be as lethal to deep-sea embryos as high pressures are to shallow living embryos, possibly restricting depths at which Lamellibrachia luymesi and sp. 1 colonize. As temperature and pressure often act in concert forming complex biological 
interactions (Somero, 1992b; Aquino-Souza et al., 2008), simultaneous changes in these parameters are likely factors controlling distributions of the Lamellibrachia tubeworms.

Contact zones between different lineages are often located in areas of narrow overlap in environmental conditions (Rocha et al., 2005). Lamellibrachia luymesi and.sp. 1 occur in adjacent depth ranges along the Louisiana Slope, however, the groups may co-occur at the extremities of their upper and lower depth ranges. There are currently no records of Lamellibrachia luymesi and sp. 1 co-occurring within the same seep site; however, we note that very few sites near this depth have been sampled in the Gulf of Mexico (Roberts et al., 2007; Becker et al., 2011). Nonetheless, co-existence of different tubeworm species within the same site and even aggregation is well documented. Lamellibrachia sp. 1, sp. 2, and Escarpia laminata co-occur in the same aggregations from five of the nine lower slope sites investigated in this study, while Lamellibrachia luymesi, Seepiophila jonesi, and a currently undescribed Escarpia-like vestimentiferan, have all been found within the same aggregations on the upper Louisiana slope (Bergquist et al., 2002, 2003a, b; Becker et al. 2011).

Different species co-existing in the same location often do so by exploiting different niches (Root, 1967). Co-existence of multiple, yet similar, vestimentiferan species within a single aggregation suggests that each species has a specific niche. For example, on the upper Louisiana slope, $S$. jonesi grows with its plume near the sediment/seawater interface and likely supplements sulfide uptake across its plume, while Lamellibrachia luymesi grows more upright and primary sulfide acquisition occurs across its posterior roots" (Julian et al., 1999; Freytag et al., 2001, Cordes et al., 2006, 2009). Finally, reproductive asynchrony can reduce temporal overlap of reproductive activities (Calabrese and Fagan, 2004) and be responsible for reproductive isolation. If Lamellibrachia luymesi and sp. 1 experience regions of environmental overlap and differential-breeding periods, this factor could reinforce their genetic differentiation.

Analyses of polymorphic microsatellite markers in this study thus show that despite possible geographic overlap, gene flow between Lamellibrachia luymesi and $\mathrm{sp}$. 1 is restricted. At present, these data support the presence of two distinct genotypic groups, which is congruent with differing morphology and depth ranges, thus suggesting that Lamellibrachia luymesi and sp. 1 are distinct biological species and follow the same species replacement pattern seen in the majority of cold seep fauna in the Gulf of Mexico (Cordes et al., 2010).

\subsection{Low levels of genetic structure detected across region in Lamellibrachia sp. 1 and sp. 2}

Submarine canyons may influence gene flow if propagules are unable to cross these boundaries due to physiological or environmental constraints (Etter et al., 2005; Rex \& Etter, 2010). In the deep Gulf of Mexico, analyses identify the presence of one undifferentiated populations of Lamellibrachia sp. 1 and sp. 2, suggesting that larvae are able to move across the canyon unrestricted. The inherent difficulties of obtaining collections from remote deep-sea habitats are well known (Gage \& Tyler, 1991), and we suggest that more individuals need to be collected and analyzed to increase the reliability of these results. However, analyses here provide evidence for a lack of genetic structure between west and east regions for both Lamellibrachia sp. 1 and sp. 2, and illustrate that 
gene flow is continuous across the region over a distance of $650 \mathrm{~km}$ for both groups. All $\mathrm{F}_{\mathrm{ST}}$ values were between $0-0.05$, considered very low levels of genetic differentiation (Hartl and Clark 2007). Low levels of genetic structure have been recorded for populations of other seep vestimentiferans, including, Lamellibrachia luymesi and Seepiophila jonesi, in which there was minimal genetic structure detected across sites on the upper Louisiana Slope (McMullin et al. 2010). Additionally, no population structure was detected at the regional level for Escarpia laminata across eight Gulf of Mexico sites (Cowart et al. 2013).

The broad geographic distributions are likely achieved by several factors, including the high dispersal capability of the larvae, coupled with oceanic currents speeds and directions. Furthermore, low temperatures encountered in the deep-sea often result in lower metabolic rates (slower utilization of energy reserves) that increases larval life and thus dispersal distances (Shilling \& Manahan, 1994; Young et al., 1997b).

Deep currents below $1000 \mathrm{~m}$ in the GoM are complex and turbulent, and difficulties of gathering information at these depths are reflected in a paucity of definitive conclusions about these currents (Hamilton 1990). In the Gulf of Mexico, topographic Rossby Waves are known to be important components of deep wave activity, and are estimated to move at speeds of $15-30 \mathrm{~cm} / \mathrm{s}$ in the central and western basin, with durations of about one month at depths below 1000 m (Hamilton 1990, Chelton \& Schlax 1996, Hamilton 2007). These speeds and directions provide a route for the movement of larvae across the gulf basin. Furthermore, there are more than 50 currently known chemosynthetic sites with biological communities distributed across the Gulf of Mexico (Tyler \& Young, 1999; Mineral Management Services, 2006; Cordes et al., 2010); within a given depth range, these communities contain the same array of species of seep dwellers, suggesting a general lack of barriers to dispersal for these deep living fauna in the Gulf of Mexico.

\section{Acknowledgements}

We would like to thank the following people for their contribution to this project: captains, crews and expedition leaders of the DSV Johnson Sea Link II, R/V Seward Johnson ROV Jason II, the US deep submergence facility, DSV Alvin, R/V Atlantis, the NOAA vessel Ronald Brown; Drew Wham, Sophie Arnaud-Haond, Kevin Kocot, Kimberlyn Nelson, Iliana Baums, Todd LaJeunesse, Chuyna Huang, Pen-Yuan Hsing, Miles Saunders, Andrew Mendelson and Olivier Soubigou. This research was funded in part by the National Science Foundation (Award \# 1209688 and IOS-0843473 to DAC and $\mathrm{KMH}$ ), the National Oceanographic Partnership Program (NOPP) through support from the Bureau of Ocean Energy Management contracts \#M05PC00018 and \#M08PC20038 to CRF (TDI Brooks International Prime), the National Oceanic and Atmospheric Administration's Office of Ocean Exploration and Research (NOAA OER), the Penn State Eberly College of Science, and an Alfred P. Sloan Scholarship to DAC. Any opinions, findings, conclusions, or recommendations expressed in this article are those of the authors and do not necessarily reflect the views of the National Science Foundation. 


\section{Author Contributions}

DAC: provided funding for research, performed research, analyzed data, and wrote the manuscript

$\mathrm{KMH}$ : provided samples for research, access to the transcriptome dataset, and edits to the manuscript

SWS: provided laboratory equipment and space for research to be conducted, assistance with the interpretation of data, and edits to the manuscript.

CRF: provided ideas, samples and funding for research, as well as edits to the manuscript

\section{References}

Andersen, A.C., Hourdez, S., Marie, B., Jollivet, D., Lallier, F.H., \& M. Sibuet, 2004. Escarpia southwardae sp nov., a new species of vestimentiferan tubeworm (Annelida, Siboglinidae) from West African cold seeps. Canadian Journal of Zoology - Revue Canadienne de Zoologie 82: 980 - 999.

Aquino-Souza, R., Hawkins, S.J., \& P.A. Tyler, 2008. Early development and larval survival of Psammechinus miliaris under deep-sea temperature and pressure conditions. Journal of the Marine Biological Association of the United Kingdom 88: 453 - 461.

Bandelt, H.J., Forster, P., A. Röhl, 1999. Median-joining networks for inferring intraspecific phylogenies. Molecular Biology and Evolution 16: 37-48.

Bazin, E., Glémin, S, \& N. Galtier, 2006. Population size does not influence mitochondrial genetic diversity in animals. Science 312: 570-571.

Becker, E.L., Macko, S.A., Lee, R.W., \& C.R. Fisher, 2011. Stable isotopes provide new insights into vestimentiferan physiological ecology at Gulf of Mexico cold seeps. Naturwissenschaften 98: 169-174.

Benjamini, Y. \& D. Yekutieli, 2001. The control of the false discovery rate in multiple testing under dependency. Annals of Statistics, 1165 - 1188.

Bergquist, D.C., Urcuyo, I.A., \& C. R. Fisher, 2002. Establishment and persistence of seep vestimentiferan aggregations on the upper Louisiana slope of the Gulf of Mexico. Marine Ecology Progress Series 241: 89-98.

Bergquist, D.C., Ward, T., Cordes, E.E., McNelis, T., Howlett, S., Kosoff, R., Hourdez, S., Carney, R., \& C. R. Fisher, 2003a. Community structure of vestimentiferan-generated habitat islands from Gulf of Mexico cold seeps. Journal of Experimental Marine Biology and Ecology 289: 197-222.

Bergquist, D.C., Andras, J.P., McNelis, T., Howlett, S., Van Horn, M.J., \& C. R. Fisher, 2003b. Succession in Gulf of Mexico cold seep vestimentiferan aggregations: the importance of spatial variability. Marine Ecology 24: 31-44. 
Black, M. B., Halanych, K. M., Maas, P. A. Y., Hoeh, W. R., Hashimoto, J., Desbruyeres, D., Lutz, R. A., \& R. C. Vrijenhoek, 1997. Molecular systematics of vestimentiferan tubeworms from hydrothermal vents and cold-water seeps. Marine Biology 130: 141-149.

Brooks J.M., Kennicutt M.C., Fisher C.R., Macko, S.A., Cole, K., Childress, J.J., Bidigare, R.R., \& R. D. Vetter, 1987. Deep-sea hydrocarbon seep communities - evidence for energy and nutritional carbon sources. Science 238: 1138-1142.

Broughton, R. E., \& R. G. Harrison, 2003. Nuclear gene genealogies reveal historical, demographic and selective factors associated with speciation in field crickets. Genetics 163: $1389-1401$.

Brown J.H., 1984. On the relationships between abundance and distribution of species. American Naturalist 124: 255 - 279.

Bruun, A., 1957. Deep sea and abyssal depths. Treatise on marine ecology and paleoecology 1: $641-672$.

Cairns, S.D., Opresko, D.M., Hopkins, T.S., \& W. W. Schroeder, 1993. New records of deep-water Cnidaria (Scleractinia \& Antipatharia) from the Gulf of Mexico. Northeast Gulf Science 13: $1-11$.

Calabrese, J.M. \& W. F. Fagan, 2004. Lost in Time: lonely and single: productive asynchrony and the Allee Effect. American Naturalist 164: 25 - 37.

Carney, R., 1994. Consideration of the oasis analogy for chemosynthetic communities at Gulf of Mexico hydrocarbon vents. Geo-Marine Letters 14: 149 - 159.

Carney, R.S., 2005. Zonation of deep biota on continental margins. Oceanography and Marine Biology: An Annual Review. Taylor and Francis. 43 211-278.

Chelton, D.S. \& M.G. Schlax, 1996. Global observations of oceanic rossby waves. Science 272: 234 - 238.

Childress, J.J. \& C. R. Fisher, 1992. The biology of hydrothermal vent animals - physiology, biochemistry and autotrophic symbioses. Oceanography and Marine Biology: an annual review 30, 337-441.

Chybicki, I. \& J. Burczyk, 2009. Simultaneous Estimation of Null Alleles and Inbreeding Coefficients. Journal of Heredity 100: 106 - 113.

Cordes, E.E., Bergquist, D.C., Predmore, B.L., Jones, C., Deines, P., Telesnicki, G. \& C. R. Fisher, 2006. Alternate unstable states: convergent paths of succession in hydrocarbonseep tubeworm-associated communities. Journal of Experimental Marine Biology and Ecology 339: 159-176.

Cordes, E.E., Carney, S.L., Hourdez, S., Carney, R.S., Brooks, J.M. \& C. R. Fisher, 2007. Cold seeps of the deep Gulf of Mexico: Community structure and biogeographic comparisons to Atlantic equatorial belt seep communities. Deep-Sea Research, Part I 54: 637-653. 
Cordes, E.E., Bergquist, D.C. \& C. R. Fisher, 2009. Macro-Ecology of Gulf of Mexico Cold Seeps. Annual Review of Marine Science 1: 143 - 168.

Cordes, E. E., Becker, E. L., Hourdez, S. \& C. R. Fisher, 2010. Influence of foundation species, depth, and location on biodiversity and structure of cold seep macrofaunal communities on the lower slope of the Gulf of Mexico. Deep-Sea Research Part II 57: 1870 $-1881$.

Cowart, D.A., Huang, C. \& S. W. Schaeffer, 2012. Identification and amplification of microsatellite loci in deep-sea tubeworms of the genus Escarpia (Polychaeta, Siboglinidae). Conservation Genetics Resources 5: 479 - 482.

Cowart, D.A., Huang, C., Arnaud-Haond, S., Carney, S.L., Fisher, C.R. \& S. W. Schaeffer, 2013. Restriction to large-scale gene flow versus regional panmixia among cold seep Escarpia spp. (Polychaeta, Siboglinidae). Molecular Ecology 22: 4147 - 4162.

Edgar, R.C., 2004. MUSCLE: multiple sequence alignment with high accuracy and high throughput. Nucleic Acids Research 32: 1792-1797.

Etter, R.J. \& M. A. Rex, 1990. Population differentiation decreases with depth in deep-sea gastropods. Deep Sea Res Part A. Oceanographic Research Papers 37: 1251 - 1261.

Etter R., Rex M.A., Chase M.R. \& J. M. Quattro, 2005. Population differentiation decreases with depth in deep-sea bivalves. Evolution 59: 1479-1491.

Excoffier, L., Smouse, P. \& J. Quattro, 1992. Analysis of molecular variance inferred from metric distances among DNA haplotypes: Application to human mitochondrial DNA restriction data. Genetics 131: 479 - 491.

Freytag, J.K., Girguis, P.R., Bergquist, D.C., Andras, J.P., Childress, J.J. \& C. R. Fisher, 2001. A paradox resolved: Sulfide acquisition by roots of seep tubeworms sustains net chemoautotrophy. Proceedings of the National Academy of Science of the United States of America 98: 13408 - 13413.

Gage, J.D. \& P. A. Tyler, 1992. Deep-sea biology: a natural history of organisms at the deep-sea floor. Cambridge University Press.

Galtier, N., Nabholz, B., Glémin, S. \& G. D. D. Hurst, 2009. Mitochondrial DNA as a marker of molecular diversity: a reappraisal. Molecular Ecology 18: 4541 - 4550.

Gelfand, Y., Rodriguez, A. \& G. Benson, 2006. TRDB - The Tandem Repeat Database. Nucleic Acids Research 35: D80 - D87.

Goudet, J., 1995. FSTAT (Version 1.2): A computer program to calculate F-Statistics. Journal of Heredity 86: 485 - 486.

Hartl, D. L. \& A. G. Clark, 2007. Principles of population genetics, fourth edition. Sinauer Associates, Sunderland, Massachusetts.

Hamilton, P., 1990. Deep currents in the Gulf of Mexico. Journal of Physical Oceanography 20: 1180 - 1207. 
Hamilton, P., 2007. Deep-Current Variability near the Sigsbee Escarpment in the Gulf of Mexico. Journal of Physical Oceanography 37: 708 - 726.

Hebert, P.D.N., Ratnasingham, S. \& J. R. de Waard, 2003. Barcoding animal of life: cytochrome c oxidase subunit 1 divergences among closely related species. Proceedings of the Royal Society of London Part B 270: S96 - S99.

Howell, K., Rogers, A., Tyler, P. \& D. M. Billett, 2004. Reproductive isolation among morphotypes of the Atlantic seastar species Zoroaster fulgens (Asteroidea: Echinodermata). Marine Biology 144: 977 - 984.

Jennings, R.M., Etter, R.J. \& L. Ficarra, 2013. Population differentiation and species formation in the deep sea: the potential role of environmental gradients and depth. PloS One 8: e77594.

Johns, GC, Avise, JC (1998) A Comparative Summary of Genetic Distances in the Vertebrates from the Mitochondrial Cytochrome b Gene. Molecular Biology and Evolution 15: $1481-1490$.

Jones, M., 1985. On the Vestimentifera, new phylum: six new species, and other taxa, from hydrothermal vents and elsewhere. Bulletin of the Biological Society of Washington 6: 117 $-158$.

Julian, D., Gaill, F., Wood, E., Arp, A.J. \& C. R. Fisher, 1999. Roots as a site of hydrogen sulfide uptake in the hydrocarbon seep vestimentiferan. Lamellibrachia sp. Journal of Experimental Biology 202: 2245 - 2257.

Kalinowski, S., 2005. HP-RARE 1.0: a computer program for performing rarefaction on measures of allelic richness. Molecular Ecology Resources 5: 187 - 189.

Kennicutt, M.C., Brooks, J.M., Bidigare, R.R. \& G. J. Denoux, 1988. Gulf of Mexico hydrocarbon seep communities-l. Regional distribution of hydrocarbon seepage and associated fauna. Deep-Sea Research Part A, Oceanographic Research Papers 35: 1639 1651.

Kocot, K. M., Cannon, J. T., Todt, C., Citarella, M. R., Kohn, A. B., Meyer, A., Santos, S. R., Schander, C., Moroz, L. L., Lieb, B., Halanych, K. M., 2011. Phylogenomics reveals deep molluscan relationships. Nature 477: 452-456.

Lalli, C.M. \& T. R. Parsons, 1993. Biological oceanography: an introduction. ButterworthHeinemann.

MacArthur, R.H., 1972. Geographical Ecology: patterns in the distribution of species. Princeton University Press, Princeton, New Jersey.

Maddison, W. P., \& L. L. Knowles, 2006. Inferring phylogeny despite incomplete lineage sorting. Systematic Biology 55: 21-30.

Mallet, J., 1995. A species definition for the modern synthesis. Trends in Ecology \& Evolution, 10: 294-299. 
McMullin, E.R., Hourdez, S., Schaeffer, S.W. \& C. R. Fisher, 2003. Phylogeny and biogeography of deep sea vestimentiferan tubeworms and their bacterial symbionts. Symbiosis 34: 1-41.

McMullin, E.R., Wood, J. \& S. Hamm, 2004. Twelve microsatellites for two deep sea polychaete tubeworm species, Lamellibrachia luymesi and Seepiophila jonesi, from the Gulf of Mexico. Molecular Ecology Notes 4: 1-4.

McMullin, E., Nelson, K., Fisher, C.R. \& S. W. Schaeffer, 2010. Population structure of two deep sea tubeworms, Lamellibrachia luymesi and Seepiophila jonesi, from the hydrocarbon seeps of the Gulf of Mexico. Deep-Sea Research Part I 57: 1499 - 1509.

Meirmans, P. \& P.W. Hedrick, 2011. Assessing population structure: FST and related measures. Molecular Ecology Research 11: 5 - 18.

Miglietta, M.P., Hourdez, S., Cowart, D.A., Schaeffer, S.W. \& C. R. Fisher, 2010. Species boundaries of Gulf of Mexico vestimentiferans (Polychaeta, Siboglinidae) inferred from mitochondrial genes. Deep-Sea Research Part II 57: 1916 - 1925.

Minerals Management Service Gulf of Mexico, 2006. Gulf of Mexico OCS Oil and Gas Lease Sales: 2007-2012. Western Planning Area Sales 204, 207, 210, 215, and 218. Central Planning Area Sales 205, 206, 208, 213, 216, and 222. Draft Environmental Impact Statement. Volume II, pp. 1 - 170, Figure 173-179, page 115. U.S. Department of the Interior.

Miura, T., Tsukahara, J. \& J. Hashimoto, 1997. Lamellibrachia satsuma, a new species of vestimentiferan worms bay, Japan. Proceedings of the Biological Society of Washington 110: 447 - 456 .

Miura, T. \& S. Kojima, 2006. Two new species of vestimentiferan tubeworm (Polychaeta: Siboglinidae aka Pogonophora) from the Brothers Caldera, Kermadec Arc, South Pacific Ocean. Species Diversity 11: 209 - 224.

Moalic, Y., Arnaud-Haond, S., Perrin, C., Pearson, G.A. \& E. A. Serrao, 2011. Travelling in time with networks: Revealing present day hybridization versus ancestral polymorphism between two species of brown algae, Fucus vesiculosus and F. spiralis. BMC Evolutionary Biology 11: 33 - 46.

Oliphant, A., Thatje, S., Brown, A., Morini, M., Ravaux, J. \& B. Shillito, 2011. Pressure tolerance of the shallow-water caridean shrimp Palaemonetes varians across its thermal tolerance window. Experimental Biology 214: 1109-1117.

Palumbi, S., 1994. Genetic divergence, reproductive isolation, and marine speciation. Annual Review of Ecology, Evolution and Systematics 25: 547 - 572.

Pradillon, F. \& F. Gaill, 2007. Pressure and life: some biological strategies. Reviews in Environmental Science and Bio/Technology 6: 181 - 195.

Pritchard, J.K., Stephens, M. \& P. Donnelly, 2000. Inference of population structure using multilocus genotype data. Genetics 155: 945-959. 
R Core Development Team, 2009. R: A language and environment for statistical computing. R Foundation for Statistical Computing, Vienna, Austria

Raymond, M. \& F. Rousset, 1995. GENEPOP (version 1.2): population genetics software for exact tests and ecumenicism. Journal of Heredity 86: 248-249.

Rex, M.A. \& R. J. Etter, 2010. Deep-sea biodiversity: pattern and scale. Harvard University Press.

Roberts, H., Carney, R., Kupchik, M., Fisher, C.R., Nelson, K., Becker, E., Goehring, L., Lessard-Pilon, S., Telesnicki, G., Bernard, B., Brooks, J., Bright, M., Cordes, E., Hourdez, S., Hunt, J., Shedd, W., Boland, G., Joye, S., Samarkin, V., Bernier, M., Bowles, M., MacDonald, I., Niemann, H., Petersen, C., Morrison, C. \& J. Potter, 2007. ALVIN explores the deep northern Gulf of Mexico slope. EOS Transactions American Geophysical Union 88: 341 - 342.

Rocha, L.A., Robertson, D.R., Roman, J. \& B. W. Bowen, 2005. Ecological speciation in tropical reef fishes. Proceedings of the Royal Society B: Biological Sciences 272: 573 579.

Root, R.B., 1967. The niche exploitation pattern of the blue-gray gnatcatcher. Ecological Monographs 37: 317-350.

Rozen, S. \& H. Skaletsky, 1999. Primer3 on the WWW for general users and for biologist programmers. Bioinformatics Methods and Protocols 132: 365 - 386.

Rozenfeld, A., Arnaud-Haond, S., Hernández-García, E., Eguíluz, V.M., Matías, M.A., Serrão, E. \& C. M. Duarte, 2007. Spectrum of genetic diversity and networks of clonal organisms. Journal of the Royal Society Interface 4: 1093 - 1102.

Rozenfeld, A., Arnaud-Haond, S., Hernández-García, E., Eguíluz, V.M., Serrão, E.A. \& C. M. Duarte, 2008. Network analysis identifies weak and strong links in a metapopulation system. Proceedings of the National Academy of Sciences 105: 18824 - 18829.

Sammarco, P.W., Brazeau, D.A. \& J. Sinclair, 2012. Genetic connectivity in scleractinian corals across the northern Gulf of Mexico: oil/gas platforms, and relationship to the Flower Garden Banks. PLoS One 7: e30144.

Sang, T., 2002. Utility of low-copy nuclear gene sequences in plant phylogenetics. Critical Reviews in Biochemistry and Molecular Biology 37: 121-147.

Saunders, P.M. \& N. P. Fofonoff, 1976 Conversion of pressure to depth in the ocean. Deep-Sea Research 23: 109 - 111.

Schluter, D.N. \& L. M. Nagel, 1995. Parallel speciation by natural selection. American Naturalist 146: 292 - 301.

Schneider, S. \& H. Lischer, 2009. ARLEQUIN, version 3.5. An integrated software package for population genetics data analysis. University of Berne, Berne.

Schuelke, M., 2000. An economic method for the fluorescent labeling of PCR fragments. Nature Biotechnology 18: 233 - 234. 
Shilling, F.M. \& D. T. Manahan, 1994. Energy metabolism and amino acid transport during early development of Antarctic and temperate echinoderms. Biological Bulletin 187: 398 407.

Sibuet, M. \& K. Olu, 1998. Biogeography, biodiversity and fluid dependence of deep-sea cold-seep communities at active and passive margins. Deep-Sea Research Part II 45: 517 567.

Simonsen, K.L., Churchill, G.A. \& C. F. Aquadro, 1995. Properties of statistical tests of neutrality for DNA polymorphism data. Genetics 141: 413-429

Somero, G.N., 1992a. Biochemical ecology of deep-sea animals. Cellular and Molecular Life Sciences, 48: 537 - 543.

Somero, G.N., 1992b. Adaptations to high hydrostatic pressure. Annual Review of Physiology 54: 557 - 577.

Southward, E.C., 1991. Three new species of Pogonophora, including two vestimentiferans, from hydrothermal sites in the Lau Back-arc Basin (Southwest Pacific Ocean). Journal of Natural History 25: 859 - 881.

Southward, E.C., Andersen, A.C. \& S. Hourdez, 2011. Lamellibrachia anaximandri n. sp., a new vestimentiferan tubeworm (Annelida) from the Mediterranean, with notes on frenulate tubeworms from the same habitat. Zoosystema 33: 245-279.

Stauffer D. \& A. Aharony, 1994. Introduction to Percolation Theory, Francis T, editor. London.

Storey, J. \& R. Tibshirani, 2003. Statistical significance for genomewide studies. Proceedings of the National Academy of Sciences 100: 9440 - 9445.

Tajima, F., 1989. Statistical method for testing the neutral mutation hypothesis by DNA polymorphism. Genetics 123: 585 - 595.

Tamura, K., \& M. Nei, 1993. Estimation of the number of nucleotide substitutions in the control region of mitochondrial DNA in humans and chimpanzees. Molecular Biology and Evolution 10: 512-526.

Tamura, K., Nei, M. \& S. Kumar, 2004. Prospects for inferring very large phylogenies by using the neighbor-joining method. Proceedings of the National Academy of Sciences 101: $11030-11035$.

Tamura, K, Peterson, D,, Perterson, N, Stecher, G, Nei, M, \& S. Kumar, 2011. MEGA5: Molecular Evolutionary Genetics Analysis using Maximum Likelihood, Evolutionary Distance, and Maximum Parsimony Methods. Molecular Biology and Evolution 28: 27312739.

Thompson, J.D., Higgins, D.G. \& T. J. Gibson, 1994. CLUSTAL W: improving the sensitivity of progressive multiple sequence alignment through sequence weighting, position-specific gap penalties and weight matrix choice. Nucleic Acids Research 22: 4673 - 4680. 
Gage, J. D., \& P. A. Tyler, 1991. Deep-sea biology: a natural history of organisms at the deep-sea floor. Cambridge University Press.

Tyler, P.A. \& C. M. Young, 1998. Temperature and pressure tolerances in dispersal stages of the genus Echinus (Echinodermata: Echinoidea): prerequisites for deep-sea invasion and speciation. Deep-Sea Research Part II 45: 253 - 277.

Tyler, P.A. \& C. M. Young, 1999. Reproduction and dispersal at vents and cold seeps. Journal of the Marine Biological Association of the United Kingdom 79: 193-208.

Valentini, A., Pompanon, F. \& P. Taberlet, 2009. DNA barcoding for ecologists. Trends in Ecology and Evolution 24: 110-117.

van der Land, J., NØrrevang, A., 1975. The systematic position of Lamellibrachia [sic] (Annelida, Vestimentifera). Journal of Zoological Systematics and Evolutionary Research Forsch (Sonderheft), 86 - 101.

van Oosterhout, C.H., Hutchinson, W.F., Willis, D.P. \& P. Shipley, 2004. Micro-checker: software for identifying and correcting genotyping errors in microsatellite data. Molecular Ecology Notes 4: 535-538.

Watts, D.J., 2004. The "new" science of networks. Annual Review of Sociology, 30, 243270.

Webb, M., 1969. Lamellibrachia barhami, gen. nov., sp. nov. (Pogonophora), from the northeast Pacific. Bulletin of Marine Science 19: 18 - 47.

Wright, S., 1951. The genetic structure of populations. Annual Eugeneics 15: 323 - 354.

Young, C.M. \& P. A. Tyler, 1993. Embryos of the deep-sea echinoid Echinus affinis require high pressure for development. Limnology and Oceanography 38: 178 - 181.

Young, C.M., Vazquez, E., Metaxas, A. \& P. A. Tyler, 1996. Embryology of vestimentiferan tube worms from deep-sea methane/sulphide seeps. Nature 381: 514-516.

Young, C., Tyler, P.A. \& L. Fenaux, 1997b. Potential for deep sea invasion by Mediterranean shallow water echinoids: pressure and temperature as stage-specific dispersal barriers. Marine Ecology Progress Series 154: 197 - 209.

Young, C., He, R., Emlet, R.B., Li, Y., Qian, H., Arellano, S.M., Gaest, A.V., Bennett, K.C., Wolf, M., Smart, T.I. \& M. E. Rice, 2012. Dispersal of deep-sea larvae from the IntraAmerican seas: simulations of trajectories using ocean models. Integrative and Comparative Biology 52: 483 - 496. 
Tables

Table 1: Locations of seep sites sampled for the microsatellite portion of the study. $N$ refers to the number of individuals analyzed, and regions are defined as either west or east of the Mississippi Canyon ${ }^{a}$.

\begin{tabular}{|c|c|c|c|c|c|c|}
\hline Taxa & Seep Name & Latitude & Longitude & Depth (m) & $N$ & $\begin{array}{c}\text { GoM } \\
\text { Region }\end{array}$ \\
\hline \multirow{4}{*}{$\begin{array}{l}\text { Lamellibrachia luymesi } \\
\qquad \mathrm{N}=21\end{array}$} & GC234 & $27.747^{\circ} \mathrm{N}$ & $91.224^{\circ} \mathrm{W}$ & 550 & 9 & West \\
\hline & GC184 & $27.782^{\circ} \mathrm{N}$ & $91.508^{\circ} \mathrm{W}$ & 540 & 2 & West \\
\hline & MC751 & $28.063^{\circ} \mathrm{N}$ & $89.707^{\circ} \mathrm{W}$ & 627 & 8 & East \\
\hline & VK826 & $29.157^{\circ} \mathrm{N}$ & $88.019^{\circ} \mathrm{W}$ & 446 & 2 & East \\
\hline \multirow{8}{*}{$\begin{array}{l}\text { Lamellibrachia } \mathrm{sp.} 1 \\
\qquad \mathrm{~N}=24\end{array}$} & GC852 & $27.095^{\circ} \mathrm{N}$ & $91.265^{\circ} \mathrm{W}$ & 1437 & 6 & West \\
\hline & WR269 & $26.677^{\circ} \mathrm{N}$ & $91.665^{\circ} \mathrm{W}$ & 1975 & 3 & West \\
\hline & AC601 & $26.392^{\circ} \mathrm{N}$ & $94.514^{\circ} \mathrm{W}$ & 2335 & 2 & West \\
\hline & GC600 & $27.374^{\circ} \mathrm{N}$ & $90.573^{\circ} \mathrm{W}$ & 1193 & 4 & West \\
\hline & GB697 & $27.312^{\circ} \mathrm{N}$ & $92.638^{\circ} \mathrm{W}$ & 1281 & 3 & West \\
\hline & MC294 & $28.675^{\circ} \mathrm{N}$ & $88.481^{\circ} \mathrm{W}$ & 1385 & 3 & East \\
\hline & MC344 & $28.633^{\circ} \mathrm{N}$ & $88.169^{\circ} \mathrm{W}$ & 1800 & 1 & East \\
\hline & DC673 & $28.516^{\circ} \mathrm{N}$ & $87.518^{\circ} \mathrm{W}$ & 2604 & 2 & East \\
\hline \multirow{6}{*}{$\begin{array}{l}\text { Lamellibrachia sp. } 2 \\
\qquad \mathrm{~N}=31\end{array}$} & GC852 & $27.095^{\circ} \mathrm{N}$ & $91.265^{\circ} \mathrm{W}$ & 1437 & 3 & West \\
\hline & WR269 & $26.677^{\circ} \mathrm{N}$ & $91.665^{\circ} \mathrm{W}$ & 1975 & 1 & West \\
\hline & MC294 & $28.675^{\circ} \mathrm{N}$ & $88.481^{\circ} \mathrm{W}$ & 1385 & 14 & East \\
\hline & MC344 & $28.633^{\circ} \mathrm{N}$ & $88.169^{\circ} \mathrm{W}$ & 1800 & 9 & East \\
\hline & DC673 & $28.516^{\circ} \mathrm{N}$ & $87.518^{\circ} \mathrm{W}$ & 2604 & 2 & East \\
\hline & WFE & $26.040^{\circ} \mathrm{N}$ & $84.915^{\circ} \mathrm{W}$ & 3304 & 2 & East \\
\hline
\end{tabular}

${ }^{a}$ regions defined as per Cairns et al., 1993 and McMullin et al. 2010. Seeps are named for the Bureau of Ocean Energy Management Lease block in which they occur. 
Table 2: Characteristics of six microsatellite loci developed for Lamellbrachia

\begin{tabular}{|c|c|c|c|c|c|}
\hline Locus & Primers $\left(5^{\prime}-3^{\prime}\right)$ & Repeat Motif & Size Range (bp) & $T_{m}\left({ }^{\circ} \mathrm{C}\right)$ & Source \\
\hline $\mathrm{L} 1-2 \mathrm{E} \# 2^{\mathrm{a}^{\mathrm{b}}}$ & $\begin{array}{l}\text { F:GGCAATTGTTGAGGACGTGT } \\
\text { R:GGAAGTGAACCAATGCTCTG }\end{array}$ & $(\mathrm{CAC} / \mathrm{AG})_{12}$ & $341-359$ & 62 & McMullin et al. 2004 \\
\hline $\mathrm{L} 454{ }_{1} 1^{\mathrm{a}}$ & $\begin{array}{l}\text { F: GGGAGGTCTTGAGAGCAGAT } \\
\text { R: CTATTCCAACATTGCACACCT }\end{array}$ & $(\mathrm{GCAC})_{14}$ & $123-278$ & 54 & This study \\
\hline $\mathrm{L} 454{ }_{1} 3^{\mathrm{a}}$ & $\begin{array}{l}\text { F: CATCATCGCTACCATCATCA } \\
\text { R: ACCTTCCAAGCATGCGGT }\end{array}$ & $(\mathrm{CAA})_{20}$ & $149-284$ & 54 & This study \\
\hline $\mathrm{L} 454{ }_{1} 9^{\mathrm{ab}}$ & $\begin{array}{l}\text { F: CTGCCCAAGCAGACATTTAT } \\
\text { R: CGCCAGGTACAGGTATTGTC }\end{array}$ & $(\mathrm{CAG})_{15}$ & $103-151$ & 54 & This study \\
\hline $\mathrm{L} 454 \_20^{\mathrm{ab}}$ & $\begin{array}{l}\text { F: GCTGATGTTGATGTTGATGC } \\
\text { R: AAGTTCAACTGCAGGGTCG }\end{array}$ & $(\mathrm{CGA})_{13}$ & $93-117$ & 54 & This study \\
\hline $\mathrm{L} 454 \_32^{\mathrm{ab}}$ & $\begin{array}{l}\text { F: CACTTTCAAGCATGCGGT } \\
\text { R: CATCATCGCTACCATCATCA }\end{array}$ & $(\mathrm{TTG})_{19}$ & $149-179$ & 53 & This study \\
\hline
\end{tabular}

aLoci amplified in Lamellibrachia sp. 1

${ }^{\mathrm{b}}$ Loci amplified in Lamellibrachia sp. 2

$\mathrm{T}_{m}=$ Annealing temperature 
Table 3: Summary statistics for six microsatellite loci amplified in Lamellibrachia luymesi and sp. 1.

\begin{tabular}{|c|c|c|c|c|c|c|c|c|}
\hline \multicolumn{2}{|c|}{ Morphospecies } & L1-2E\#2 & L454_11 & L454_13 & L454_19 & L454_20 & L454_32 & Mean $\pm S E$ \\
\hline \multirow{6}{*}{$\begin{array}{l}\text { L. luymesi } \\
\mathrm{N}=20\end{array}$} & $N_{A}$ & 6 & 13 & 8 & 3 & 6 & 8 & 7.33 \\
\hline & $H_{O}$ & 0.53 & 0.80 & 0.65 & 0.16 & 0.75 & 0.66 & 0.59 \\
\hline & $H_{E}$ & 0.57 & 0.89 & 0.69 & 0.15 & 0.63 & 0.69 & 0.60 \\
\hline & $F_{I S}$ & 0.08 & 0.11 & 0.06 & -0.04 & -0.19 & 0.04 & 0.02 \\
\hline & $A R$ & 2.63 & 4.66 & 3.28 & 1.45 & 2.87 & 3.35 & $3.04 \pm 0.43$ \\
\hline & $P_{A R}$ & 0.92 & 4.66 & 3.28 & 0.21 & 1.74 & 1.89 & $2.12 \pm 0.48$ \\
\hline \multirow{6}{*}{$\begin{array}{l}\text { L. sp } 1 . \\
\mathrm{N}=24\end{array}$} & $N_{A}$ & 4 & 19 & 10 & 7 & 3 & 7 & 8.33 \\
\hline & $H_{O}$ & 0.82 & 0.79 & 0.23 & 0.76 & 0.66 & 0.43 & 0.61 \\
\hline & $H_{E}$ & 0.62 & 0.94 & 0.84 & 0.73 & 0.52 & 0.45 & 0.68 \\
\hline & $F_{I S}$ & -0.34 & $0.16^{*}$ & $0.73 *$ & -0.05 & -0.27 & 0.03 & 0.10 \\
\hline & $A R$ & 2.70 & 5.17 & 4.18 & 3.32 & 2.09 & 2.42 & $3.32 \pm 0.66$ \\
\hline & $P_{A R}$ & 0.99 & 5.17 & 4.18 & 2.08 & 0.97 & 0.96 & $2.40 \pm 0.75$ \\
\hline \multicolumn{2}{|c|}{ Lamellibrachia sp. 1} & L1-2E\#2 & L454_11 & L454_13 & L454_19 & L454_20 & L454_32 & Mean $\pm S E$ \\
\hline \multirow{6}{*}{ West GoM } & $N_{A}$ & 3 & 18 & 9 & 7 & 5 & 6 & 8.00 \\
\hline & $H_{O}$ & 0.78 & 0.78 & 0.19 & 0.70 & 0.72 & 0.39 & 0.59 \\
\hline & $H_{E}$ & 0.61 & 0.96 & 0.83 & 0.73 & 0.54 & 0.35 & 0.67 \\
\hline & $F_{I S}$ & -0.28 & 0.19 & 0.78* & 0.04 & -0.33 & -0.11 & 0.12 \\
\hline & $A R$ & 2.61 & 5.39 & 1.05 & 3.39 & 2.40 & 2.10 & $3.32 \pm 0.50$ \\
\hline & $P_{A R}$ & 0.35 & 3.66 & 1.80 & 1.10 & 0.30 & 0.69 & $1.40 \pm 0.52$ \\
\hline \multirow{6}{*}{ East GoM } & $N_{A}$ & 4 & 8 & 6 & 3 & 4 & 4 & 4.80 \\
\hline & $H_{O}$ & 1.00 & 0.83 & 0.33 & 1.00 & 1.00 & 0.60 & 0.79 \\
\hline & $H_{E}$ & 0.71 & 0.89 & 0.89 & 0.75 & 0.79 & 0.73 & 0.79 \\
\hline & $F_{I S}$ & -0.48 & 0.07 & $0.65^{*}$ & -0.41 & -0.30 & 0.20 & -0.01 \\
\hline & $A R$ & 3.16 & 4.74 & 4.50 & 2.96 & 3.48 & 3.33 & $3.70 \pm 0.30$ \\
\hline & $P_{A R}$ & 0.91 & 3.01 & 2.25 & 0.68 & 1.37 & 1.93 & $1.74 \pm 0.36$ \\
\hline
\end{tabular}

Abbreviations: $N_{A}$, number of alleles observed; observed $\left(H_{O}\right)$ and expected $\left(H_{E}\right)$ heterozygosity, $F_{I S}$, Wright's Inbreeding Coefficient; $A R$, rarified allelic richness (rarefied over six samples); $P_{A R}$, private allele richness; $S E$, standard error.

${ }^{*}$ denotes significant deviation from HWE after FDR correction $=0.01$ 
Table 4: Summary of Analysis of Molecular Variance (AMOVA) conducted for each study under the Infinite Allele Model, $F_{\text {ST. }}$

\begin{tabular}{|c|c|c|c|c|c|}
\hline Study & $\begin{array}{l}\text { Source of } \\
\text { Variation } \\
\end{array}$ & d.f. & SS & Variation $(\%)$ & p-value \\
\hline \multirow{3}{*}{$\begin{array}{l}\text { Lamellibrachia } \\
\text { (Two taxa) }\end{array}$} & Within individuals & 44 & 81.00 & 81.30 & --- \\
\hline & Among individuals & 42 & 86.63 & 4.90 & 0.049 \\
\hline & Among populations & 1 & 15.65 & 13.80 & $0.001 *$ \\
\hline \multirow{3}{*}{ Lamellibrachia sp.1 } & Within individuals & 24 & 46.00 & 91.60 & --- \\
\hline & Among individuals & 22 & 50.17 & 8.30 & $0.036^{*}$ \\
\hline & Among populations & 1 & 2.28 & 0.10 & 0.486 \\
\hline \multirow{3}{*}{ Lamellibrachia sp. 2} & Within individuals & 31 & 39.00 & 100.00 & --- \\
\hline & Among individuals & 27 & 30.80 & 0.00 & 0.608 \\
\hline & Among populations & 3 & 1.77 & 0.00 & 0.838 \\
\hline
\end{tabular}

Abbreviations: d.f, degrees of freedom; SS, sum of squares.

* denotes significance, tested using 1000 permutations. 
Table 5: Summary statistics for four microsatellite loci amplified in three regional populations of Lamellibrachia sp. 2.

\begin{tabular}{|c|c|c|c|c|c|c|}
\hline \multicolumn{2}{|c|}{ Lamellibrachia sp. 2} & L12E\#2 & L454_19 & L454_20 & L454_32 & Mean $\pm S E$ \\
\hline \multirow{6}{*}{$\begin{array}{c}\text { West GoM } \\
\text { (WR269 and } \\
\text { GC852) }\end{array}$} & $N_{A}$ & 2 & 4 & 3 & 2 & 2.75 \\
\hline & $H_{O}$ & 0.50 & 1.00 & 0.50 & 0.25 & 0.56 \\
\hline & $H_{E}$ & 0.50 & 0.82 & 0.68 & 0.25 & 0.56 \\
\hline & $F_{I S}$ & 0.00 & -0.26 & 0.29 & 0.00 & 0.00 \\
\hline & $A R$ & 2.00 & 3.00 & 2.41 & 1.50 & $2.23 \pm 0.31$ \\
\hline & $P_{A R}$ & 1.00 & 0.12 & 0.49 & 0.45 & $0.52 \pm 0.18$ \\
\hline \multirow{6}{*}{$\begin{array}{c}\text { East GoM } \\
\text { (MC294 and } \\
\text { MC344) }\end{array}$} & $N_{A}$ & 5 & 5 & 4 & 5 & 4.75 \\
\hline & $H_{O}$ & 0.81 & 0.64 & 0.56 & 0.43 & 0.61 \\
\hline & $H_{E}$ & 0.67 & 0.76 & 0.57 & 0.38 & 0.59 \\
\hline & $F_{I S}$ & -0.22 & 0.15 & 0.00 & -0.14 & -0.03 \\
\hline & $A R$ & 2.53 & 2.80 & 2.10 & 1.81 & $2.31 \pm 0.22$ \\
\hline & $P_{A R}$ & 1.06 & 0.40 & 0.06 & 0.65 & $0.54 \pm 0.21$ \\
\hline \multirow{6}{*}{$\begin{array}{c}\text { Far East } \\
\text { GoM } \\
\text { (DC673 and } \\
\text { WFE) }\end{array}$} & $N_{A}$ & 2 & 3 & 3 & 2 & 2.50 \\
\hline & $H_{O}$ & 1.00 & 1.00 & 1.00 & 0.25 & 0.81 \\
\hline & $H_{E}$ & 0.60 & 0.83 & 0.73 & 0.25 & 0.60 \\
\hline & $F_{I S}$ & -1.00 & -0.30 & -0.50 & 0.00 & -0.50 \\
\hline & $A R$ & 2.00 & 3.00 & 2.60 & 1.50 & $2.28 \pm 0.33$ \\
\hline & $P_{A R}$ & 0.48 & 0.36 & 0.78 & 0.38 & $0.50 \pm 0.10$ \\
\hline
\end{tabular}

Abbreviations: $N_{A}$, number of alleles; observed $\left(H_{O}\right)$ and expected $\left(H_{E}\right)$ heterozygosity, $F_{I S}$, Wright's Inbreeding Coefficient; $A R$, rarified allelic richness (rarefied over six samples); $P_{A R}$, private allele richness; SE, standard error.

* denotes significant deviation from HWE after FDR correction $=0.01$ 


\section{Figure Captions}

Figure 1 Gulf of Mexico (GoM) cold seep sites sampled for this study. 1000 meter contours from NASA-JPL Advanced Spaceborne Thermal Emission and Reflection Radiometer (http://www.geomapapp.org). Lamellibrachia luymesi = red circles, Lamellibrachia sp. $1=$ orange circles and Lamellibrachia sp. 2 = green circles

Figure 2 Median-joining haplotype networks of the mtCYTB and HbB2i. Colors represent Lamellibrachia luymesi (blue) and Lamellibrachia sp. 1 (red). Sizes of haplotype circles and are proportional to the number of individuals possessing the same sequence and each line represents one mutational change separating two haplotypes. The HbB2i network includes additional haplotypes for the heterozygous individuals

Figure 3 Top: STRUCTURE results (admixture model, three replicate runs) for Lamellibrachia luymesi (blue) and Lamellibrachia sp. 1 (red). Each vertical bar represents an individual tubeworm. The $y$-axis is the proportion of each individual's genotype belonging to a distinct population cluster. Bottom: Network topologies of Lamellibrachia luymesi (blue) and sp. 1 (red) individuals from the Rozenfeld Distance model (RD) based on eight shared microsattelite markers. Shared Allele Distance (SAD) model results are not shown. Only links with value smaller than or equal to the percolation distances are present. Nodes (circles) represent individuals. Two clusters are identified, one for each Lamellibrachia population 


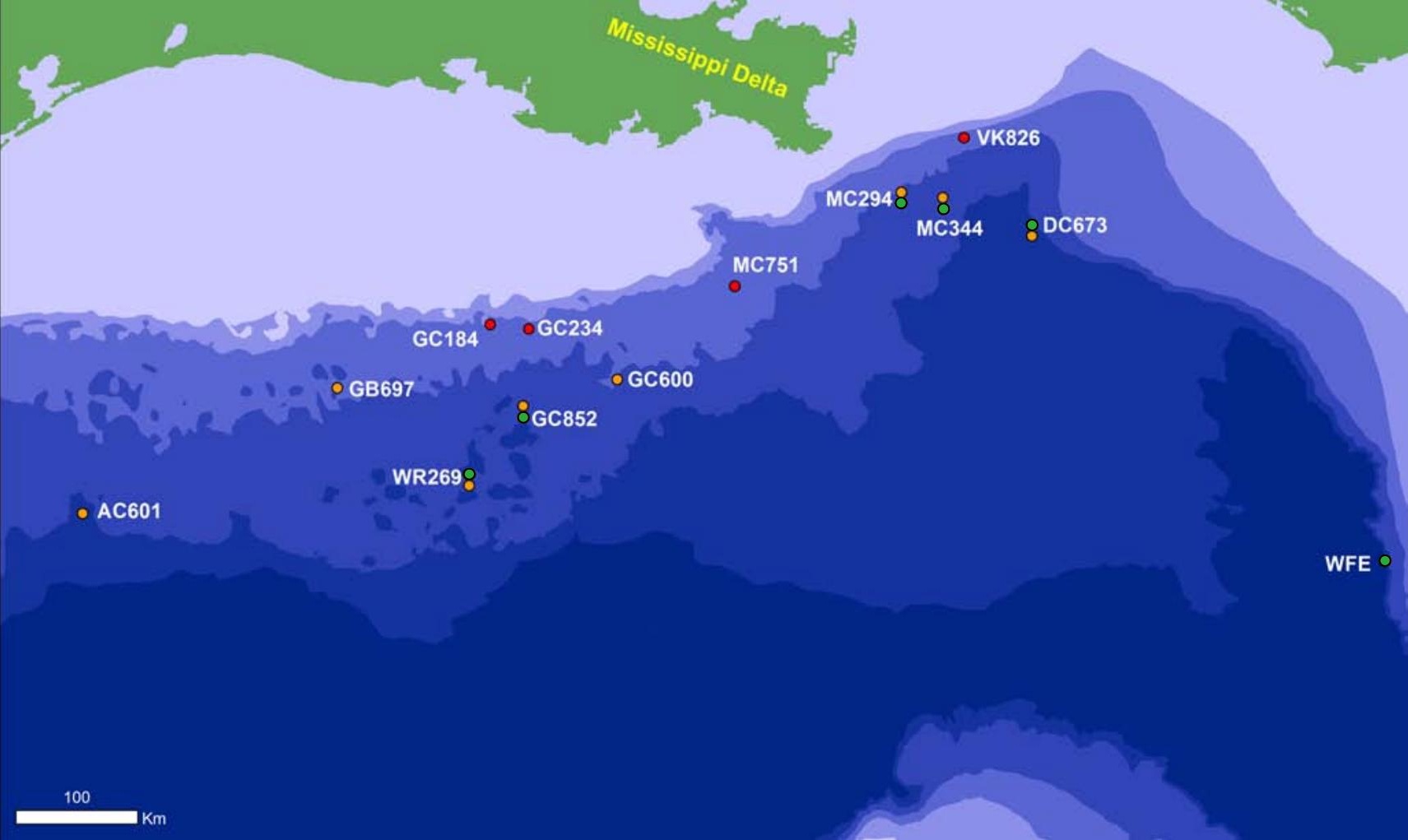




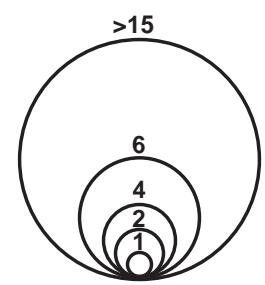

1 change
mtCYTB

380bp

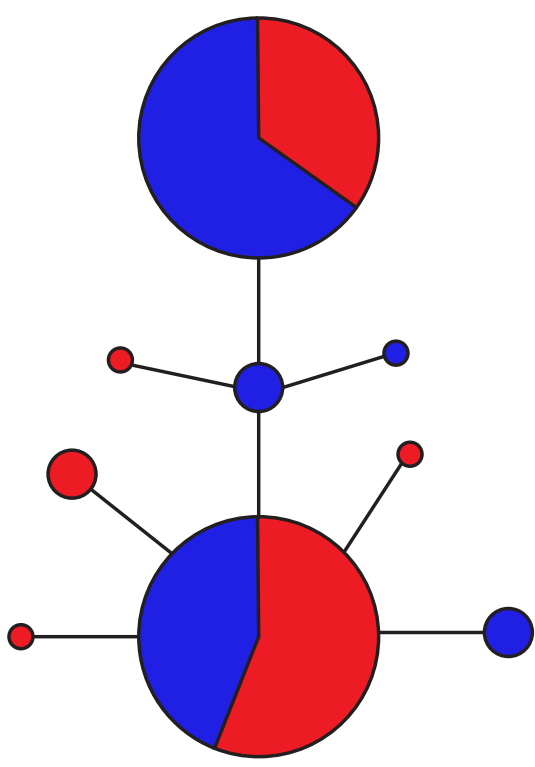

HbB2i

668bp

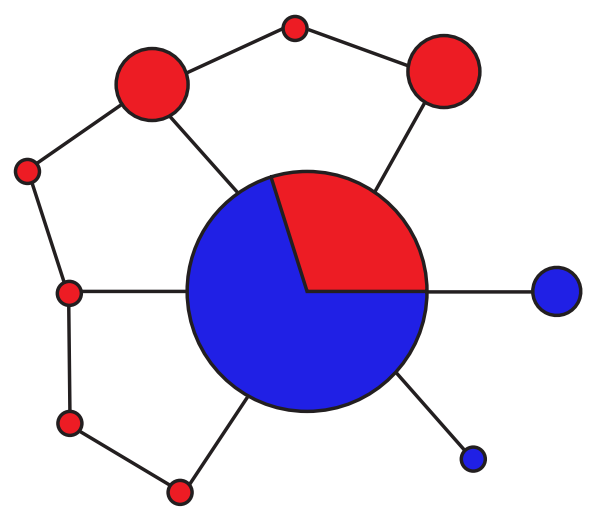




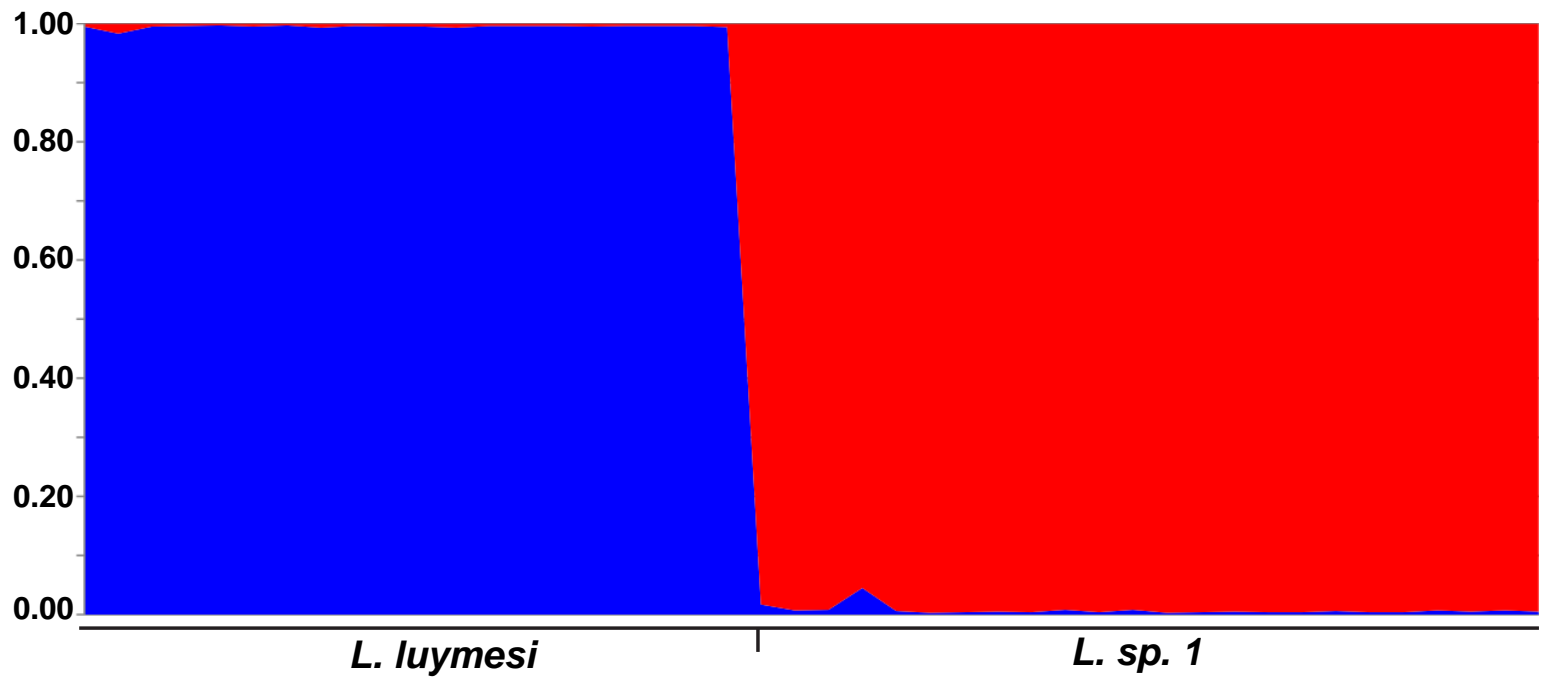

Dpe $=\mathbf{7 5 . 0 0}$

Dpe $=63.00$

Dpe $=\mathbf{5 0 . 0 0}$

L. sp. 1
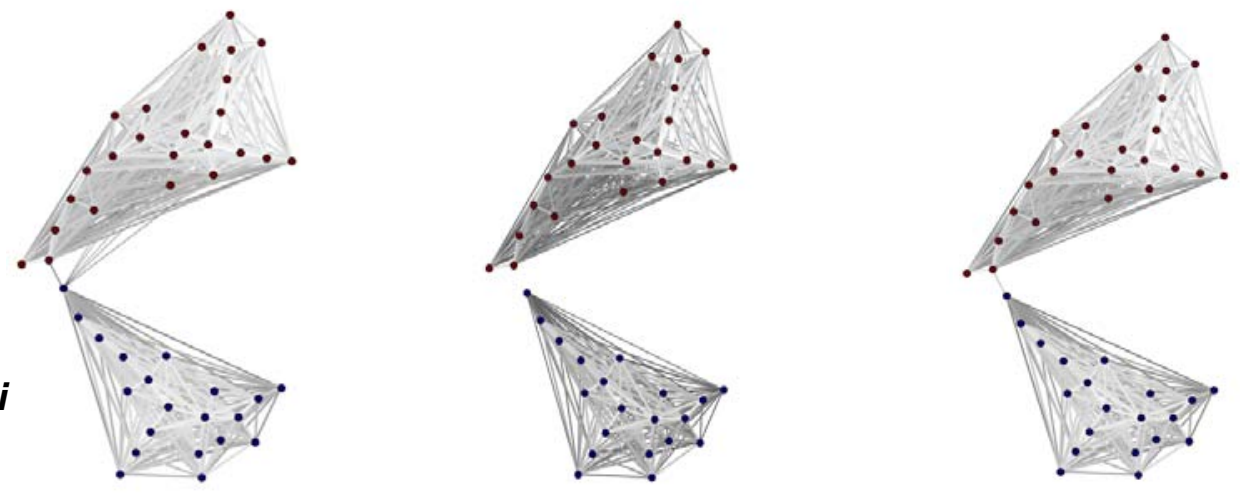